JANUSZ GRYGIEŃĆ

Instytut Politologii UMK

\title{
"Okrucieństwo miłosierdzia". O źródłach popularności projektów eugenicznych w krajach anglosaskich u progu XX wieku
}

\author{
Skrajnym okrucieństwem jest trosz- \\ czenie się o nicponiów kosztem ludzi \\ wartościowych. To umyślne ściąganie \\ nieszczęść na przyszłe pokolenia. \\ Największym przekleństwem dla po- \\ tomnych jest obarczenie ich rosnącą \\ populacją imbecyli ${ }^{1}$
}

E ugenika to dziś nauka wyklęta, postrzegana jako zideologizowany zbiór teorii, reprezentujący interesy klasy lub narodu, oparty na rasizmie i implikujący praktyki ludobójcze, do których zresztą bezpośrednio - pod postacią Holocaustu - doprowadziła. Występuje tym samym wyraźna tendencja do utożsamiania wiary w jej prawdziwość z moralną ułomnością właściwą nazistowskim oficjałom i ich równie amoralnym, bezwzględnie oddanym złej sprawie, podwładnym. Gdy jednak dokonuje się takiego uproszczenia, gdy ruch eugeniczny sprowadza się do Niemiec okresu hitleryzmu, gdy pomija się osobiste zaangażowanie i poparcie, jakiego eugenicznym ideom udzieliły takie sławy świata nauki i kultury, jak: Alexander Graham Bell, George Bernard Shaw, Herbert George Wells; tak wytrawni politycy, jak: Theodore Roosevelt i Winston Churchill, ryzykuje się równoczesne pominięcie faktu, że eugenika to nie tylko domena - zamkniętych w swych laboratoriach - zwariowanych naukowców, ale, pociągająca ludzi racjonalnych i jednocześnie wrażliwych, idea wyleczenia ludzkości z wszelkich ułomności o charakterze tak fizycznym, jak i moralnym.

Jak doszło do tego, że teorie dziś oceniane tak jednoznacznie negatywnie, jeszcze niedawno cieszyły się szerokim uznaniem? Bez wątpienia podatny grunt dla rozwoju idei eugenicznych przygotowały teorie społecz-

M. Sanger, Pivot of Civilization, New York 1922, s. 105, cyt. za: E. Black, Wojna przeciw słabym. Eugenika i amerykańska kampania na rzecz stworzenia rasy panów, Warszawa 2004, s. 208. 
no-ekonomiczne końca XVIII i połowy XIX wieku. Opublikowany w 1798 roku malthusiański An Essay on the Principle of Population, który poczytnością zaskoczył samego autora (w niespełna trzydzieści lat doczekał się sześciu wydań), łączący elementy historiozoficznego pesymizmu z oświeceniowym racjonalizmem, uznać można za swoistą zapowiedź późniejszych idei klasyków eugeniki. Thomas Malthus utrzymywał w swej pracy, że przyrost społeczny, odbywający się w postępie geometrycznym, zawsze będzie wyprzedzał podobny przyrost zasobów żywnościowych, dokonujący się w postępie arytmetycznym. Dlatego też, pozostawiony swobodnemu rozwojowi, porządek społeczno-ekonomiczny nie będzie zmierzał w kierunku dobrobytu ludzkości. Przeciwnie, koniecznym skutkiem wszelakich prób realizacji projektów świata pozbawionego wojen, zaraz, morderstw, aborcji i homoseksualizmu, świata bezustannie wydłużającego się okresu życia, musi być głód i ubóstwo całych społecznych mas. Już wydanie drugie An Essay... zawierało pewną modyfikację teoretyczną, zakładającą możliwość powstrzymania tego niepożądanego i pozornie nieuchronnego rozwoju. Abstynencja seksualna, przede wszystkim zaś porzucenie wszelkich projektów ekonomicznego wspierania najuboższych (w Anglii usankcjonowanego przez różnorakie ustawy - poczynając od Poor Law Act z 1601 po, bezpośrednio poprzedzające wydanie An Essay..., ustanowienie w 1795 systemu Speenhamland) uznał Malthus za środki niezbędne dla uchronienia się przed powszechną pauperyzacją i głodem.

Choć zupełnie inne podłoże miała myśl Darwina i Spencera, oni także przyczynili się do rozwoju idei eugenicznych. Pierwszy z nich (którego syn, major Leonard Darwin, jeden z głównych działaczy tego ruchu, był wieloletnim przewodniczącym British Eugenics Society) w swym sławnym 0 powstawaniu gatunków, nie kryjąc długu wdzięczności wobec Malthusa, otwarcie przyznawał, że jego własne koncepcje stanowią przeniesienie społecznych idei An Essay... na grunt ogólnoprzyrodniczy ${ }^{2}$. Spencer z kolei, gorliwy przeciwnik państwowego interwencjonizmu, wierzył w społeczny charakter „walki o byt", mającej eliminować jednostki najsłabiej przystosowane, która ostatecznie prowadzić miała do realizacji ściśle pozytywistycznej wizji racjonalnego społeczeństwa typu przemysłowego. W opublikowanych w 1863 roku Principles of Biology stwierdzał istnienie fizjologicznych czynników odpowiedzialnych za tego typu rozwój.

O ile jednak dzieła powyżej wymienionych myślicieli można uznać za, co najwyżej, stymulujące intelektualny zwrot w pewnym konkretnym kierunku rozważań, o tyle autorów tych nie można uznać za twórców „nauko-

C. Darwin, On the Origin of Species by Means of Natural Selection or the Preservation of Favoured Race in the Struggle for Life, London 1859, s. 18. 
wej" eugeniki. Takie teoretyczne podstawy zapewnily dopiero koncepcje dwóch innych badaczy: angielskiego podróżnika, lekarza, antropologa i matematyka - Francisa J. Galtona i brneńskiego augustianina - Gregora Mendla. Obaj, choć każdy na inny sposób, przyczynili się do rozwoju teorii dziedziczności. Mendel to twórca praw dziedziczenia nazwanych jego imieniem: prawa czystości gamet, prawa niezależnej segregacji i prawa dominacji, stanowiących jedną z podstaw współczesnej genetyki. Galton zaś, którego imię do dziś nosi największa eugeniczna instytucja brytyjska, zasłynął już za życia m.in. dzięki innowacyjnej publikacji Finger Prints, mającej przełomowe znaczenie dla kryminalistyki, Hereditary Genius, w której rozwijał koncepcję dziedziczenia nie tylko cech fizycznych, ale także charakterologicznych oraz Natural Inheritance, gdzie dokonał próby ścisłego określenia genetycznych relacji między rodzicami i ich potomstwem. Jemu też przypisuje się powszechnie, zarówno zapoczątkowanie eugenicznego ruchu, jak i utworzenie samego terminu ,eugenika”.

Choć pierwsze kroki jako nauka stawiała eugenika w Europie, jej losy na przełomie wieków i w pierwszych dziesięcioleciach wieku XX, w znacznej mierze wiązały się z kontynentem północnoamerykańskim. To w USA zaisniały specyficzne warunki, umożliwiające bardzo szybki rozwój tego nowo powstałego ruchu. Przede wszystkim, miał tu miejsce - zakrojony na szeroką skalę - mariaż nauki z finansjerą. Gdyby nie wsparcie, jakiego Charlesowi Benedictowi Davenportowi, najbardziej znaczącemu teoretykowi i praktykowi pozostającemu pod wpływem Galtona, i Harry'emu Hamiltonowi Laughlinowi udzieliły rodziny Carnegie, Rockefeller, Harriman oraz instytucje, takie jak: American Breeders Association, znaczenie ruchu zapewne nigdy nie osiągnęłoby tak pokaźnych rozmiarów. $Z$ drugiej zaś strony, gdyby nie fakt, że młody amerykański naród przyjmował bezustannie setki tysięcy nowych imigrantów z całego globu, stopienie których w jedno, w tzw. The Melting Pot dla wielu wydawało się czystą fikcją, być może brakłoby osób przekonanych o potrzebie obrony przed „skundleniem” narodu amerykańskiego, rozcieńczeniem krwi tradycyjnych WASPs. Nigdzie indziej w tym okresie ruch eugeniczny nie otrzymał tak dużego wsparcia ze strony władz centralnych i stanowych, wszelkich publicznych instytucji prowadzących rejestry interesantów, okolicznych mieszkańców, pacjentów, przestępców czy właśnie przekraczających granice imigrantów. W żadnym innym kraju nie przeprowadzano, na aż tak szeroką skalę, zabiegów sterylizacji osób, których potomstwo bez wątpienia szkodziłoby interesowi Ameryki - epileptyków, osób 
psychicznie chorych i przestępców - tych tzw. Jukesów $w^{3}$, którzy z pokolenia na pokolenie zaludniali przestrzeń między dwoma oceanami, czyniąc ją piekłem dla dobrych, praworządnych obywateli.

Charakterystyczny dla USA był także sojusz zawarty między eugeniką i ruchem feministycznym reprezentowany przez osobę Margaret Sanger. Choć Davenport i Laughlin odcinali się od działań aktywistycznych, które ich zdaniem nie szły w parze z naukowością badań i wyników prac eugenicznych instytucji, faktem jest, że feministyczna American Birth Control League przyczyniła się do popularyzacji postulatów eugeniki negatywnej i minimalizacji państwowego interwencjonizmu.

Długa lista instytucji bezpośrednio eugenikę wspierających, tłumaczy poniekąd jej popularność wśród intelektualnych elit. W USA do najbardziej znanych, oprócz tych już wymienionych, jej przedstawicieli zaliczyć można m.in. laureatów Nagrody Nobla - Hermana Mullera, Linusa Paulina, Joshua Lederberga, Williama Shockleya, prezydentów uniwersytetów w Yale (Irving Fisher), Harvardzie (Charles Wilson), Stanford i Indiana (David Starr Jordan), sędziego Sądu Najwyższego - Oliviera Wendella Holmesa. Nie inaczej było w Wielkiej Brytanii, gdzie do zwolenników eugeniki zaliczano m.in. Bertranda Russella, Sir Juliana Huxleya - pierwszego sekretarza generalnego UNESCO, Johna Maynarda Keynesa, Sir Williama Beveridge'a i Artura Balfoura.

Mimo podobnej popularności, eugenika brytyjska, w porównaniu z tą zza wielkiej wody, na początku XX nie prezentowała się równie okazale. Mimo tego, że tu także dało o sobie znać przeludnienie miast związane z rozwojem przemysłu, za którym szedł wzrost przestępczości i emigracji, aktywność eugeników brytyjskich pozostawała w dalekim tyle za tą, cechującą ich amerykańskich kolegów. Nie chodziło wyłącznie o wsparcie, jakie od agend rządowych otrzymywali ci ostatni, lecz także o śmiałość w wyciąganiu praktycznych wniosków z teorii Galtona i Mendla. Tę odzwierciedlał przede wszystkim stopień nacisku, który kładziono na pozytywny bądź negatywny projekt eugeniczny. Eugenika pozytywna, której propagatorzy za swe główne cele obierali uświadamianie władzom i obywatelom możliwości genetycznego kreowania struktury społecznej, upatrywała podstaw tego typu działań w dobrowolnej zgodzie i współdziałaniu wszystkich obywateli. Ten sposób myślenia cechował $\mathrm{w}$ większym stopniu Brytyjczyków. Amerykanie przeważnie kładli nacisk na konieczność działań przymusowych i zinstytucjona-

Por. R.L. Dugdale, The Jukes. A Study in Crime, Pauperism, Disease and Heredity, also Further Studies of Criminals, New York 1877, gdzie autor zebrał dane 42 rodzin ze społecznego marginesu i wyliczył koszta ponoszone przez państwo zapobiegające ich kolejnym zbrodniom, karzące te już dokonane i udzielające zapomóg tym z nich, którzy pozostają bezrobotnymi (zob. E. Black, dz. cyt., s. 62). 
lizowanych. Głoszony przez nich program eugeniki negatywnej opierał się na postulatach m.in. izolacji i sterylizacji osób niepożądanych z punktu widzenia przyszłości narodu. Rozbieżności teoretyczne między eugeniczną rzeczywistością na Wyspach i w USA uległy minimalizacji po utworzeniu w 1908 roku brytyjskiego Towarzystwa Edukacji Eugenicznej, już wówczas zdominowanego przez badaczy odcinających się od, ostrożnych w swych sądach, stronników samego Galtona.

Dziwi dziś to, że możliwą była uległość elit intelektualnych wiktoriańskiej i edwardiańskiej Anglii wobec idei, co do której oczywistym wydaje się, że w sposób nieunikniony prowadzić musiała do tragedii. Faktem pozostaje jednak, że w Anglii początku XX wieku miał miejsce szeroko zakrojony sojusz największych politycznych sił, zawiązany w imię ustanawiania ograniczeń zagrożenia rozprzestrzeniania wad genetycznych. Jak pisze Freeden, „tym co zaskakuje w tych tezach jest nie tylko brak ich ugruntowania w faktach, lecz także absencja jakiegokolwiek, opartego na liberalnych lub humanitarnych podstawach, protestu wobec możliwego ograniczenia wolności i nieodwracalności proponowanych «lekarstw»" ${ }^{4}$. Głosy poparcia dla pomysłów tworzenia zakładów zamkniętych i sterylizacji osób chorych wychodziły tak ze środowisk liberalnych, jak i socjalistycznych. Powszechnie podzielane wówczas przekonanie o nieograniczonych możliwościach rozwoju społeczeństwa brytyjskiego, znajdowało ujście w nowym sposobie zabiegania o społeczny dobrobyt. Duchowi przywódcy rosnących w polityczną siłę tzw. Nowych Liberałów, J.A Hobson i L.T. Hobhouse, choć częstokroć nie szczędzący krytycznych uwag pod adresem czołowych eugeników, jednocześnie otwarcie opowiadali się za świadomą ingerencją w życie obywateli dla eliminacji cech niepożądanych. Różnili się jedynie w takich kwestiach jak pytanie, czy bardziej pożądanym jest, by te działania inspirowane były przez opinię publiczną, czy też instytucje państwowej administracji, czy na ostateczny obraz dziedzicznych cech wpływ ma środowisko, w którym do pewnego stopnia są rozwijane, czy też czynniki te pozostają względnie niezależnymi.

Nie bez znaczenia była też prowadzona w tym okresie dyskusja o zakresie i przeznaczeniu państwowego interwencjonizmu. Okazało się, że każda ze stron sporu prezentowała poglądy ostatecznie kompatybilne z postulatami eugeników. Ci, którzy za paradygmatem manchesterskiej szkoły liberalizmu, opowiadali się za minimalizmem administracyjnym, uważali się częstokroć za kontynuatorów myśli Spencera, a więc i spadkobierców koncepcji fizjologicznych determinantów psychiki i „przemysłowej walki o byt”. Podobne poparcie znajdowały idee eugeniczne wśród społecznych reformato-

$4 \quad$ M. Freeden, The New Liberalism. An Ideology of Social Reform, Oxford 1978, s. 178. 
rów przekonanych o konieczności zorganizowanej pomocy potrzebującym. Mowa między innymi o działaczach Charity Organization Society, którzy przyjmowali za cel swych działań taką pomoc najuboższym, która jednocześnie nie odbierałaby im motywacji dla rozwijania cech samodzielności i odpowiedzialności oraz osobach zaangażowanych $\mathrm{w}$ charytatywne przedsięwzięcia anglikańskiej Christian Social Union.

Nie oznacza to, że propaganda eugeniczna nie napotkała intelektualnego oporu. Przybierał on zróżnicowane formy. Z jednej strony wykorzystywał tok argumentacyjny samych eugeników - ich przeciwnicy twierdzili, że darwinowska ewolucja oraz spencerowska naturalna eliminacja jednostek najsłabiej przystosowanych, najintensywniej dokonuje się właśnie wśród społecznych „dołów”. To nie doskonale funkcjonujący w społeczeństwie, wywodzący się z klas średnich i wyższych przedsiębiorcy czy finansiści, są najbardziej pożądanymi z genetycznego punktu widzenia osobnikami. To ci, urodzeni w slumsach self-made men, których bezlitosna dla słabeuszy londyńska ulica nauczyła sprytu, odwagi i umiejętności podejmowania szybkich i trafnych decyzji, stanowią element społeczny, z którym należałoby wiązać przyszłość brytyjskiego imperium.

Z drugiej strony, nie był zupełnie nieobecnym otwarty sprzeciw w imię samego ideału indywidualnej wolności. Sławną i symptomatyczną jednocześnie dla zakresu tego sprzeciwu była dyskusja nad Mental Deficiency Act z 1912 roku, ustawą przewidującą przymusową izolację chorych umysłowo $\mathrm{w}$ - specjalnie do tego celu przeznaczonych - zakładach. Tylko jeden głos krytyczny podniósł się ze strony posłów liberalnych. Był to głos Josiah Wedgwooda, wówczas niezbyt już w samej Partii Liberalnej popularnego, późniejszego polityka Partii Pracy. Swoistą kombinację obydwu tych sposobów argumentacji przedstawiały środowiska związane z liberalną „Nation”.

Najbardziej jednoznaczną i doniosłą w skutkach krytykę eugeniki przeprowadziły jednak środowiska katolickie. Powoływały się one w swym sprzeciwie na ogłoszoną w 1930 roku przez Piusa XI encyklikę Casti Connubi, w której papież dał wyraz potrzebie bezwarunkowego odrzucenia wszelkich postulatów kontroli narodzin, zakazu małżeństw osób postrzeganych przez eugeników za genetycznie „upośledzone” i ich sterylizacji. W 1931 roku kolejne dwa papieskie dokumenty potępiły zarówno negatywną, jak i pozytywną eugenikę.

Swoje zarzuty formułowały też ośrodki akademickie, głównie amerykańskie. Najgłośniejszy sprzeciw dochodził z John Hopkins University (od Raymonda Pearla i Herberta Spencera Jenningsa), z University of Texas (od Hermana Josepha Mullera) i Columbia University (od Thomasa Hunta Morgana). Środowiska te wypominały eugenikom niemożliwość precyzyjnego 
określenia kryteriów uznawania za upośledzonego umysłowo (feebleminded), posługiwanie się niezweryfikowanymi hipotezami naukowymi (np. „plazmy zarodkowej") oraz nieuzasadnione ignorowanie wpływu środowiska na rozwój cech charakteru.

Autor eseju Eugenics and Progressive Thought, Michael Freeden, to mało w Polsce znany profesor University of Oxford. Głównymi przedmiotami jego zainteresowań są: brytyjska myśl liberalna początku XX wieku ${ }^{5}$ oraz kwestia ideologizacji dyskursu politycznego ${ }^{6}$. Zagadnienie eugeniki niejednokrotnie pojawia się na kartach jego książek, zazwyczaj w odniesieniu do tych właśnie obszarów wiedzy. Podobnie jak w publikowanym tu (pierwotnie zaś w „The Historical Journal") artykule, tak też w pozostałych swych książkach ten problem poruszających, stara się zrozumieć Freeden podłoże zainteresowania, jakim cieszył się projekt eugeniczny wśród intelektualnych elit brytyjskich. Dlaczego ludzi darzących się niekiedy olbrzymią antypatią z racji wyznawanych poglądów politycznych i społecznych jednoczyła teoria, która w imię humanitaryzmu albo sprzeczności z prawem naturalnym powinna być raczej bezwzględnie potępioną i powszechnie odrzuconą? Freeden, szkicując obraz relacji brytyjskich przywódców politycznych różnych opcji do idei eugenicznych, stara się na to pytanie udzielić odpowiedzi. Nie traci przy tym nadziei, że, nawet jeśli jest możliwa do odkrycia, prawda o społecznej świadomości tamtych czasów może być przez współczesnego Europejczyka pojęta i zaakceptowana.

\footnotetext{
Tamże; Tenże, Liberalism divided: a study in British political thought, 1914-1939, Oxford 1986; Tenże, Reappraising J.A. Hobson: humanism and welfare, London-Boston 1990.

$6 \quad$ Tenże, Ideologies and political theory: a conceptual approach, Oxford 1996; Tenże, Reassessing political ideologies: the durability of dissent, London-New York 2001; Tenże, Liberal languages: ideological imaginations and twentieth-century progressive thought, Princeton 2005; Taking ideology seriously: 21st century reconfigurations, M. Freeden, G. Talshir, M. Humphrey (red.), London-New York 2006; The Meaning of Ideology: Cross-Disciplinary Perspectives, M. Freeden (red.), Abingdon 2007.
} 